\title{
TOXIC CYANOBACTERIA AND WILDLIFE CONSERVATION: PROPOSAL OF A PROCEDURE TO DEMONSTRATE WATERBIRD MASS MORTALITIES BY MICROCYSTIN
}

\author{
María Aránzazu MATEOS-SANZ, Daniel CARRERA, \\ Victoria LÓPEZ-RODAS \& Eduardo COSTAS* \\ Departamento de Producción Animal, Genética, Facultad de Veterinaria, Universidad Complutense de \\ Madrid, Avda. Puerta de Hierro s/n, 28040 Madrid, Spain \\ *Corresponding author: ecostas@vet.ucm.es
}

Recibido el 15 de septiembre de 2009, aceptado para su publicación el 2 de octubre de 2009 Publicado "on line" en octubre de 2009

\begin{abstract}
Toxic cyanobacteria and wildlife conservation: proposal of a procedure to demonstrate waterbird mass mortalities by microcystin. The role of toxic cyanobacteria in wildlife conservation is poorly known. However, toxic cyanobacteria blooms could have a very important effect on wildlife. In particular, mass mortalities of waterbirds are receiving improved attention in recent years because of their increased occurrence. Cyanobacteria toxicosis by microcystins (potent hepatotoxic cyclic peptides) should be taken in account as a significant cause of such mortalities in eutrophic inland water systems. A suitable procedure to diagnose waterbird mortalities due to toxin-producing cyanobacteria (microcystins) should be based on five sequential steps: i) macroscopic in situ evaluation searching evidences of cyanobacteria blooms; ii) identification of toxic cyanobacteria species; iii) analysis of water samples searching for microcystin detection; iv) epidemiology and clinical sings; and v) post-mortem examination of waterbirds to verify that microcystins reach to digestive system of birds. This procedure was employed to analyze recent mortalities of waterbirds in Doñana National Park (S Spain), revealing that toxicosis by microcystins was the main cause of the worst mass mortality.
\end{abstract}

Keywords. Cyanobacteria, diagnostic procedure, Doñana National Park, microcystins, waterbird mortalities, wildlife refuge.

RESUMEN. Cianobacterias tóxicas y conservación de la vida salvaje: propuestas de un procedimiento para demostrar mortalidades en masa de avifauna causadas por microcistina. El papel que desempeñan las cianobacterias tóxicas en la conservación de la fauna salvaje está subestimado. Sin embargo, las proliferaciones de cianobacterias tóxicas pueden tener un efecto importante sobre la vida salvaje. Particularmente las mortandades masivas de aves acuáticas están siendo objeto de atención en los últimos años debido a su considerable incremento. Se debería tener en cuenta que las toxicosis cianobacterianas, especialmente por microcystinas (potentes peptidos hepatotóxicos), podrían ser una causa importante de mortalidad en aguas continentales. Un procedimiento adecuado para diagnosticar mortandades de aves acuáticas debidas a cianobacterias debería seguir un protocolo de cinco pasos: i) evaluación macroscópica in situ buscando evidencias de proliferación masiva de cianobacterias; ii) identificación de las especies de cianobacterias tóxicas; iii) análisis de muestras de agua para detectar microcystinas; iv) estudio de la epidemiología, y síntomas y signos clínicos; y v) examen post-mortem de las aves para verificar que las cianobacterias alcanzaron el sistema digestivo. Este procedimiento ha sido empleado para analizar los últimos casos de 
mortandades de aves acuáticas en el Parque Nacional de Doñana (S España) revelando que la toxicosis por microcistinas fue la causa de la peor mortalidad masiva de aves en la última década.

Palabras clave. Cianobacteria, microcistinas, mortalidad de aves acuáticas, Parque Nacional de Doñana, procedimiento diagnóstico, refugio de fauna salvaje.

\section{INTRODUCTION}

Cyanobacterial toxic blooms are the cause of repeated mass mortalities of wildlife refuges (Carmichael \& Hui, 2006; López-Rodas et al., 2008). In particular, waterbird species are particularly susceptible to cyanobacteria intoxication, and mass mortalities of wild birds were reported in inland water systems worldwide (Henriksen et al., 1997; Matsunaga et al., 1999; Krienitz et al., 2003). At SW Spain, Doñana National Park (DNP) is classified as a Special Protection Area for birds by the EU under Directive 79/409 because DNP provides refuge for threatened species and a place to overwinter for to over $70 \%$ European bird species. Since 1973 eighteen mass mortalities of waterbirds were reported in this wildlife refuge (Memorias PND 1975-2004) but the causes of such mortalities were unknown until 2001. It must be take into account that DNP meets all the requirements for appearing of cyanobacteria blooms in their water bodies: a marked dry season (from June to September) and, simultaneously, high temperatures, high solar radiation and very high levels of nutrients due to the high density of animals that are concentrated in the few remaining bodies of water. In this sense, in the Lucio de las Piedras (a marsh lagoon from DNP) a mass mortality of waterbirds occurred in July 2001. This event gave us the opportunity to analyze their possible causes and to establish a standard diagnosis procedure. Unsurprisingly, cyanotoxins were the cause of this mass mortality (AlonsoAndicoberry et al., 2002).

Cyanobacterial toxin are currently grouped into three main broad groups according to their models of toxicity in animals or animal- derived organs or cells: i) hepatotoxic cyclic peptides (microcystins and nodularins); ii) neurotoxic and cytotoxic alkaloids; and iii) irritants lipopolysacharides. Worldwide, hepatotoxins (microcystins and nodularins) are the cyanotoxins most frequently found are responsible of most cyanotoxicosis in animals and humans (reviewed by Sivonen \& Jones, 1999).

In this work, we propose an appropriate diagnostic procedure to detect and discriminate mortalities of waterbirds due to hepatotoxic cyclic peptide produced by cyanobacteria from other agents. During the last decade, our research group has been working in collaboration with researchers from DNP with the aim to understand the causes involved in wildlife mass mortalities. Nowadays, this procedure is been employed in a standardized manner when there was mortalities of waterbirds in DNP. As soon as cyanobacteria toxicosis is suspected, the five steps procedure summarized below should be followed.

\section{MATERIALS AND METHODS}

\section{Macroscopic evaluation in situ.}

First of all, we should to observe the affected inland water systems at naked eye. In this sense, the most reported cases affected animals consumed water from water bodies with a dense surface blue-green scum; this scum usually accumulate at leeward shore near of the surface of water bodies (Sivonen \& Jones, 1999). Consequently, we should observe two facts suspects about the presence of cyanobacteria in water, an unusually mortality of waterbirds as well as a dense surface blue 
green scum in the surface of water body.

\section{Identification of toxic species.}

Afterwards a microscopic observation of waterbloom samples should to confirm that there are toxin-producing cyanobacteria species (cyanobacteria waterblooms may be constituted by non-toxic species). A correct taxonomical identification is crucial (mistakes in taxonomic identification i.e. Botriococcus or Gomphosphaeria instead Microcystis have given a lot of false positives). Afterwards, a precise cell counting in a settling chamber allows to kwon if amount of toxic cyanobacteria is enough as to become hazardous. If toxic cyanobacteria species constitute only a very small fraction of the bloom, toxin concentration necessarily will be low. But toxin-producing cyanobacteria species densities of thousands cells $\mathrm{ml}^{-1}$ should to alert us. In this sense the review by Lawton et al. (1999) indicate methods for determining and counting toxic cyanobacteria.

\section{Analysis of water samples: microcystin detection.}

Not all blooms of toxic cyanobacteria species are producing toxins. Even within a single-species bloom of a toxic species, there may be a pool of toxic and non-toxic strains, and some strains are much more toxic than others (Carrillo et al., 2003). Consequently, it is necessary to obtain information on concentration of cyanotoxins in waterbloom. There are a lot of laboratory methods to detect and identify hepatotoxic cyclic peptides (reviewed by Harada et al., 1999). In our experience, mouse bioassays and several kits (based on phosphatase inhibition or enzyme linked immunosorbent assays) are rapid and trouble-free procedures. In mouse bioassays, hepatotoxic cyclic peptides cause death by liver damage within few hours of the dose (in contrast with neurotoxic alkaloids, which die mouse by respiratory arrest rapidly $<1 \mathrm{~h}$ ) (Sivonen $\&$
Jones, 1999). Since mouse bioassays are less sensitive than other procedures, great amount of cyanobacteria cells should be concentrated prior to bioassay. Afterwards, mouse bioassays should be confirmed using commercially available microcystin tests, which are rapid and sensitive procedures (Harada et al., 1999).

\section{Epidemiology and clinical sings.}

Waterflow poisoned by microcystin are often found dead, but live intoxicated birds may be unable to swim or fly (Bischoff \& Dabvt, 2001). However, acute death due to hepatotoxicosis is the most common signs of hepatotoxic cyclic peptides poisoning. Post-mortem inspection often reveals disruption of liver structure with hepatic enlargement generally accompanied by evidence of intrahepatic haemorrhage (Bischoff \& Dabvt, 2001). Mortalities due to infectious diseases show different patterns of epidemic curves (for example the Reed-Frost model, Kendall's waves, and others) than those of mortalities due to toxicosis (see Thrusfield, 1995 for a review of epidemic curves). Certainly, mortalities due to cyanotoxins fit to epidemic curves of acute toxicosis.

\section{Post-mortem examination of waterbirds: detection of microcystin. \\ Cyanotoxins are produced and contained} within actively growing cyanobacterial cells, but during cell senescence, death and lysis the toxins are released to water (reviewed by Sivonen \& Jones, 1999). Microcystins and nodularins, being cyclic peptides are extremely stable and may persist in water for weeks (Sivonen an\& Jones, 1999). Consequently, cyanotoxins can to arrive at stomach directly through consumption of cyanobacterial cells from water, or indirectly when animals drink water containing dissolved toxins after the end of the bloom. Several waterbirds directly eat toxin-producing cyanobacteria (Alonso-Andicoberry et al., 2002). Even, laboratory experiments showed that many times 
mammals elected to consume blooms of toxic cyanobacteria in preference to limpid water (López-Rodas \& Costas, 1999). In addition, cyanotoxins are bioaccumulated in common aquatic invertebrates and vertebrates such as zooplankton, mollusks, or fishes (reviewed by Sivonen \& Jones, 1999).

\section{To verify that cyanobacteria toxins reach to digestive system.}

Subsequently, cyanotoxins can also to arrive at stomach through consumption of other animals that have them fed on cyanobacteria. Detection and quantification of hepatotoxic cyclic peptides in stomach content should be performed just as for detection of cyanotoxins in waterblooms, but taking in account that levels of microcystins in stomach content can be many times most high than those measured in the waterbloom (Alonso-Andicoberry et $a l ., 2002)$. Significant variation in lethal doses of microcystin was found among the different species (ranged from $40 \mu \mathrm{g} \mathrm{kg}^{-1}$ in mice to 5.0 $\mathrm{mg} \mathrm{kg}^{-1}$ in some insects; reviewed by Bischoff \& Dabvt, 2001). In spite of this, sometimes the stomach content of waterbirds has as great amount of toxin as to give surety on the causes of mortality (sometimes more than $600 \mu \mathrm{g} \mathrm{g}^{-1}$; Alonso-Andicoberry et al., 2002).

\section{To confirm that hepatotoxic cyclic peptides arrive at the liver.}

Microcystins are absorbed through digestive system and accumulated in the liver (reviewed by Bischoff \& Dabvt, 2001). The liver is the target organ of microcystins and nodularins due to the presence of the bile acid transporters system (Oberholster et al., 2004). The microcystins inhibits protein phosphatases types 1 and $2 \mathrm{~A}$ in the liver, and the subsequent hyperphosphorylation due to protein phosphatase inhibition causes structural damage to hepatocytes and disorganization of hepatic structure cause death by intrahepatic haemorrhage (Bischoff \& Dabvt, 2001). In our experience, ELISA procedures are suitable to rapidly detect microcystin-nodularin in livers (Alonso-Andicoberry et al., 2002). Since inhibitory concentration 50 (IC50) for hepatotoxic cyclic peptides is only 0.04 to 8 nM (Bischoff \& Dabvt, 2001), even low levels of hepatotoxic cyclic peptides in liver should be lethal. In spite of this, the liver of waterbirds accumulates elevated toxin content (even $>$ $400 \mu \mathrm{g} \mathrm{g}^{-1}$ ) during mass mortalities (AlonsoAndicoberry et al., 2002).

\section{RESULTS AND DISCUSSION}

The procedure to diagnose cyanotoxicosis in waterbirds was addressed in DNP in order to test if it is a valid procedure. Two recent mortalities of waterbirds in DNP were analyzed using the protocol: i) c. 200 flamingos suddenly died in FAO lagoon $\left(37^{\circ} 05^{\prime} \mathrm{N}, 006^{\circ} 23^{\prime} \mathrm{W}\right)$ during summer 2003; and ii) > 5000 waterfowls and thousands fishes died during the summer 2004 in El Cherry channel $\left(36^{\circ} 58,3^{\prime} \mathrm{N}, 006^{\circ} 17^{\prime} \mathrm{W}\right)$.

Results of the application of this diagnostic procedure to detect mortalities due to hepatotoxic cyclic peptide-producing cyanobacteria are summarized in table 1 .

A dense cyanobacteria bloom composed by toxic species occurred during the mass mortality in 2004. In contrast, scarce amount of toxic cyanobacteria were identified during flamingos mortality in 2003. Great amount of hepatotoxic cyclic peptides were detected in the affected area during mass mortality in 2004, but toxins were undetectable during mortality in 2003. Ten analyzed waterbirds died during 2004 showed large amount of microcystins in both digestive tract and liver, whereas cyanotoxins were undetectable in ventriculus and liver of the eleven analyzed birds died during 2003. Finally, the birds died during 2004 showed sings of hepatic haemorrhage in contrast with flamingos died during 2003, and both mortalities showed different patterns of epidemiologic curves. 


\begin{tabular}{|c|c|c|}
\hline Diagnostic Procedure & 2003 mortality & 2004 mortality \\
\hline \multicolumn{3}{|l|}{ 1. Cyanobacteria amount in the affected area } \\
\hline Detection of cyanobacteria waterbloom & - & + \\
\hline Microcystis aeruginosa $\left(\right.$ colonies $\mathrm{ml}^{-1}$ ) & $<200$ & $>60,000$ \\
\hline Pseudanabaena catenata (colonies $\mathrm{ml}^{-1}$ ) & Not detectable & $>10,000$ \\
\hline Total cyanobacteria (colonies $\mathrm{ml}^{-1}$ ) & $<300$ & $>75,000$ \\
\hline \multicolumn{3}{|l|}{ 2. Cyanotoxin amount in the affected area } \\
\hline Mouse Bioassay & - & + \\
\hline ELISA $\left(\mu \mathrm{g} \mathrm{ml}^{-1}\right)$ & Not detectable & $>15$ \\
\hline \multicolumn{3}{|l|}{ 3. Cyanotoxin amount within crop } \\
\hline Mouse Bioassay & - & + \\
\hline ELISA $\left(\mu \mathrm{g} \mathrm{ml}^{-1}\right)$ & Not detectable & $>50$ \\
\hline 4. Cyanotoxin amount in liver $\left(\mu \mathrm{g} \mathrm{ml}^{-1}\right)$ & Not detectable & $27-76$ \\
\hline 5. Epidemiology \& clinical sings & & + \\
\hline Liver affection & - & Numerous species of \\
\hline Waterbirds affected & Only flamingos & waterbirds and fishes \\
\hline
\end{tabular}

Table 1. Application of a diagnostic procedure to detect waterbirds mortality due to hepatotoxic cyclic peptide-producing cyanobacteria. Aplicación de un procedimiento diagnóstico para detectar mortalidad de aves acuáticas debida a cianobacterias productoras de péptidos cíclicos hepatotóxicos.

These facts suggest that mass mortality of waterbirds during 2004 was due to toxicosis by cyanotoxins. In contrast, cyanotoxins were not the cause of flamingo's mortality during 2003. In fact, 2003 mortalities were due to infectious process caused by Pasteurella spp. (Lanzarot, 2007).

Under our point of view, understanding causes of waterbirds mass mortalities should be the focus of multidisciplinary investigations in ecology, epidemiology, toxicology and pathology. Cyanobacteria toxicosis should be taken in account as a possible cause of the repeated mass mortalities of waterbirds, above all in eutrophic inland water systems. The diagnostic procedure proposed here is a useful tool to detect mortalities of waterbirds caused by cyanobacteria. Moreover, this proposal could be a relevant tool to management of water in wildlife refuges as occur in DNP.

The temptation to link morphology and toxin production in cyanobacteria is very old. However an analysis of polygenic traits of $M$. aeruginosa demonstrates that there are not genetic correlation between morphological traits and microcystin production (genetic correlation: $-1.166 \pm 0.174$, non significant) (López-Rodas et al., 2006); in the same way, the residual correlations between morphological traits and microcystin production was also 
non significant. Moreover, Rico et al. (2006) have demonstrated that variability in a lot of morphological traits of cells and colonies of $M$. aeruginosa is due to environment more than genetics. Unfortunately, within a toxic cyanobacteria species, morphology is not useful to estimate toxin production.

ACKNOWLEDGEMENTS. This work is supported by Red de Alerta-Junta de Andalucía (494/2007) grant.

\section{REFERENCES}

ALONSO-ANDICOBERRY, C., L. GARCÍAVILLADA \& E. COSTAS.- 2002- Catastrophic mortality of flamingos in a Spanish national park caused by cyanobacteria. Vet. Rec. 7: 706-707.

BISCHOFF, K. \& M. S. DABVT.-2001- The toxicology of microcystin-LR: Occurrence, toxicokinetics, toxicodynamics, diagnosis and treatment. Vet. Hum. Toxicol. 43: 294-297.

CARMICHAEL, W.W. \& HUI, R.-2006Cyanobacteria toxins in the Salton Sea. Saline Systems 2: 5.

CARRILLO, E., L. M. FERRERO, C. ALONSOANDICOBERRY, A. BASANTA, A. MARTÍN, V. LÓPEZ-RODAS \& E. COSTAS.-2003Interstrain variability in toxin production in populations of the cyanobacterium Microcystis aeruginosa from water-supply reservoirs of Andalusia and lagoons of Doñana National Park (southern Spain). Phycologia 42: 269-274.

HARADA, K., F. KONDO \& L. LAWTON.-1999Laboratory analysis of cyanotoxins. In Toxic Cyanobacteria in Water I. Chorus and J. Bartram (eds.). London, E. \& F. N. Spon, pp. 369-405.

HENRIKSEN, P., W. W. CARMICHAEL, J. AN \& O. MOESTRUP.-1997- Detection of an anatoxina(s)-like anticholinesterase in natural blooms an cultures of cyanobacteria/blue-green algae from Danish lakes and in the stomach contents of poisoned birds. Toxicon 35: 901-913.

KRIENITZ, L., A. BALLOT, K. KOTUT, C. WIEGAND, S. PÜTZ, J. S. METCALF, G. A. CODD \& S. PJLUGMACHER.-2003Contribution of hot spring cyanobacteria to the mysterious deaths of Lesser Flamingos at Lake Bogoria, Kenya. Microbiol. Ecol. 43: 141-148. LANZAROT, M. P.-2007- Cianobacterias tóxicas y mortandades en masa en fauna salvaje en las marismas de Doñana. Tesis Doctoral. Facultad de Veterinaria. Universidad Complutense de Madrid.

LAWTON, L., B. MARSALEK, J. PADISÁK \& I. CHORUS.-1999-Determination of cyanobacteria in the laboratory. In Toxic Cyanobacteria in Water I. Chorus and J. Bartram (eds.). London, E. \& F. N. Spon, pp. 347-367.

LÓPEZ-RODAS, V.\& E. COSTAS.-1999-Preference of mice to consume Microcystis aeruginosa (Toxin-producing cyanobacteria): A possible explanation for numerous fatalities of livestock and wildlife. Res. Vet. Sci. 67: 107-110.

LÓPEZ-RODAS, V., E COSTAS, E. BAÑARES, L. GARCÍA-VILLADA, M. ALTAMIRANO, M. RICO, C. SALGADO \& A. FLORES-MOYA.2006- Analysis of poligenic traits of Microcystis aeruginosa (Cyanobacteria) strains by Restricted Maximum Likelihood (REML) procedures: 2. Microcystin net production, photosynthesis and respiration. Phycologia 45: 243-248.

LÓPEZ-RODAS, V.,E.MANEIRO,M.P.LANZAROT,N. PERDIGONES, \& E. COSTAS, -2008-Mass wildlife mortality due to cyanobacteria in the Doñana National Park, Spain. Vet. Rec. 162:317-8.

MATSUNAGA, H., K. I. HARADA, M. SENMA, Y. ITO, N. YASUDA, S. USHIDA \& Y. KIMURA.1999- Possible cause of unnatural mass death of wild birds in a pond in Nishinomiya, Japan: sudden appearance of toxic cyanobacteria. Nat. Toxins 7: 81-84.

MEMORIAS PARQUE NACIONALDE DOÑANA. CSIC. Estación Biológica de Doñana, Sevilla, España. Años: 1975-2004

OBERHOLSTER, P. J., A-M. BOTHA \& J. U. GROBBELAAR.-2004- Microcystis aeruginosa: source of toxic microcystins in drinking water. Afr. J. Biotech. 3: 159-168.

RICO, M., M. ALTAMIRANO, V. LOPEZ-RODAS \& E. COSTAS.-2006- Analysis of poligenic traits of Microcystis aeruginosa (Cyanobacteria) strains by Restricted Maximum Likelihood (REML) procedures: 1. Size and shape colonies and cells. Phycologia 45: 237-242.

SIVONEN, K. \& G. JONES.-1999- Cyanobacterial toxins. In Toxic Cyanobacteria in Water I. Chorus and J. Bartram (eds.). London, E. \& F. N. Spon, pp. 41-91.

THRUSFIELD, M.-1995- Veterinary Epidemiology, 2nd edition, Blackwell Science, New York, $483 \mathrm{pp}$. 